\title{
Dark walled up with stone: contrasting images of Irish Catholicism
}

\section{Colum Kenny}

\section{Q OpenEdition \\ 1 Journals}

\section{Electronic version}

URL: http://journals.openedition.org/etudesirlandaises/3938

DOI: 10.4000/etudesirlandaises.3938

ISSN: 2259-8863

\section{Publisher}

Presses universitaires de Rennes

\section{Printed version}

Date of publication: 20 November 2014

Number of pages: $79-97$

ISBN: 978-2-7535-3559-6

ISSN: 0183-973X

\section{Electronic reference}

Colum Kenny, "Dark walled up with stone: contrasting images of Irish Catholicism », Études irlandaises [Online], 39-2 | 2014, Online since 20 November 2016, connection on 02 May 2019. URL : http:// journals.openedition.org/etudesirlandaises/3938; DOI : 10.4000/etudesirlandaises.3938 


\title{
Dark Walled up with Stone: Contrasting Images of Irish Catholicism
}

\author{
Colum Kenny \\ School of Communications, Dublin City University
}

Résumé

The author contrasts current images of the Irish Catholic Church with an abiding popular narrative of the relationship between priests and people in Ireland. He notes a recent decline in church attendance and widespread criticism of church authorities but acknowledges the close association between Irish identity and Christian practice. He suggests that Irish people would welcome the discovery of a way forward for the Irish Catholic Church as a whole that might allow it to reemerge as an institution that its lay members could find relevant to their daily lives in general and to their spiritual or psychological needs in particular.

Mots clés : Avortement, évêques, Humanae Vitae, identité, laics

Abstract

L'auteur met en avant le contraste qui prévaut entre les images contemporaines de l'Eglise catholique irlandaise et le récit populaire irréductible concernant la relation qui unit les prêtres au peuple d'Irlande. Il note le déclin récent de la fréquentation des églises et la critique répandue des autorités ecclésiastiques, mais il reconnaît l'association intime entre l'identité irlandaise et la pratique catholique. Il suggère que les Irlandais seraient heureux de découvrir un moyen qui permette à l'Eglise catholique irlandaise dans son ensemble d'aller de l'avant et de ré-émerger en tant qu'institution susceptible de faire sens dans la vie quotidienne des laïcs en general et de répondre à leurs besoins spirituels et psychologiques en particulier.

Keywords: Abortion, bishops, Humanae Vitae, identity, laity

During the debate that led up to the passing of legislation on abortion in the Republic of Ireland in 2013, the Irish Catholic Bishops Conference published a video statement by Eamon Martin, who was then the coadjutor archbishop of Armagh ${ }^{1}$. It was one of a number of communications by the hierarchy that unsuccessfully sought to influence the outcome of the parliamentary vote and to defeat the bill.

1. "A time to uphold the right to life", Statement by the Catholic bishops of Ireland, June 2013 [http://www. catholicbishops.ie/2013/06/11/time-uphold-life-statement-catholic-bishops-ireland/] (viewed 17 Oct. 2014). 


\section{Colum Kenny}

A seated Archbishop Martin spoke directly to camera. Behind him was displayed a still image of people, mainly women and children, marching to the Irish parliament in Dublin on a sunny day during the preceding week. In his opening words he observed that, "On Saturday last, tens of thousands of women, men and children gathered in Dublin to express their support for the equal right to life of mothers and their unborn children". He added, "We are at a defining moment for our country".

Grab from online video statement by Archbishop Eamon Martin, June 2013, with still image of "pro-life" marchers in background

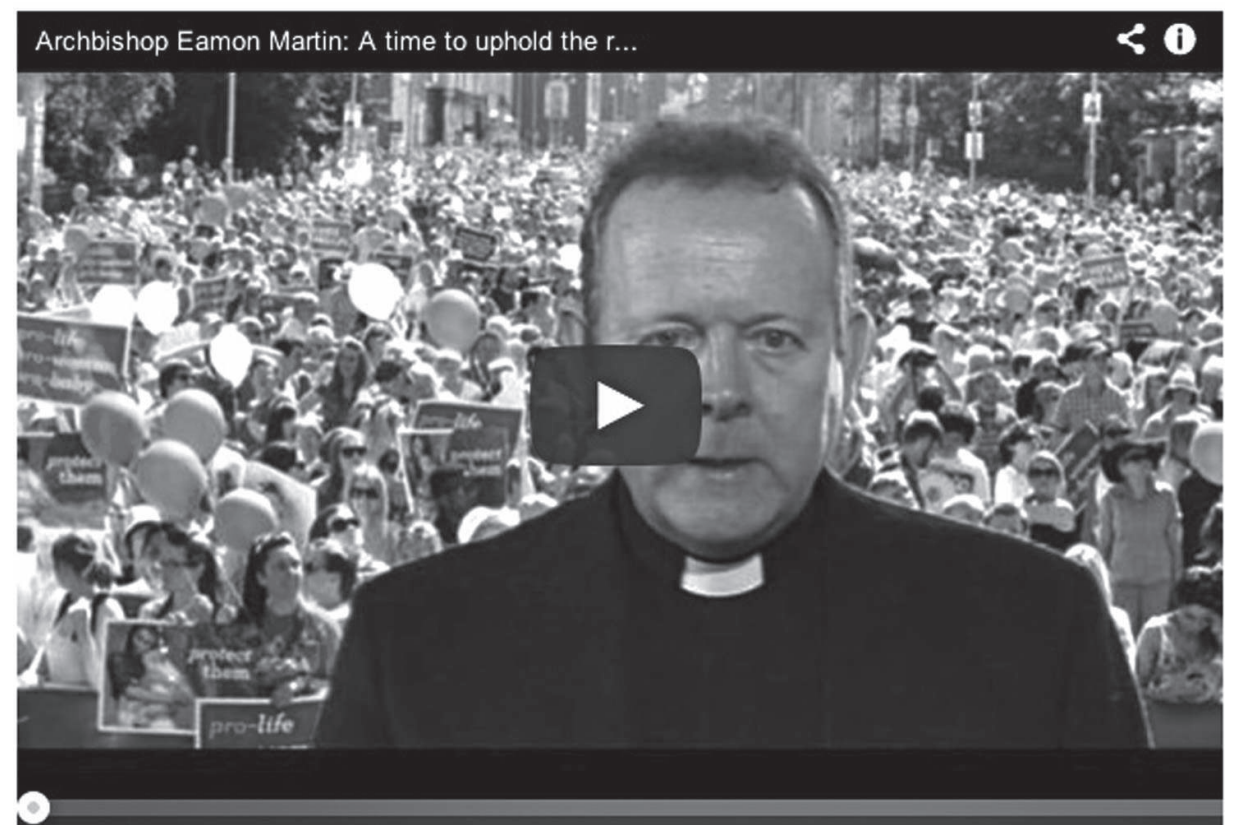

The dominant image of an unsmiling archbishop, in clerical suit and Roman collar, contrasted with that of gaily-clad women carrying coloured balloons and pink placards asserting the value of life. Whatever words came from his mouth, this visual juxtaposition might be seen to imply that women's place in the Catholic Church is in the background, and that they will be quiet when men in authority speak.

But there was an even more fundamental contrast, a primary one between darkness and light, between the black cloth of Archbishop Eamon Martin and the bright cotton tops and balloons of the women and children. The slogan "pro-life" was clearly visible just behind him on the placards held by demonstrators. 
Perhaps some advisor to the archbishop chose this backdrop deliberately to soften the hierarchy's image, to give the archbishop an appearance of "street cred[ibility]" and to suggest that the hierarchy was speaking for a silent multitude in opposition to the majority of politicians who supported the proposed law. Irish bishops are more often seen on television in front of some church structure. A more usual image of the hierarchy locates it at the gaunt Victorian complex of St Patrick's College, Maynooth, Co. Kildare, where the bishops regularly meet as a body. Eamon Martin fronting a throng of women and children was certainly different.

Or perhaps the feminine image behind him was a response to that of a solitary woman dominating TV bulletins. Savita Halappanavar, a Hindu resident in Ireland, had died during pregnancy in a Galway hospital. Her death sparked a fierce debate that had precipitated the introduction of the Protection of Life during Pregnancy Bill 2013.

The communication challenge for Irish church authorities cannot be solved by sophisticated media advisers tweaking the contexts in which bishops present their messages. On the contrary, many citizens regard such an approach as both cynical and pathetic, like the efforts of an ageing uncle to persuade young nephews that he is "with it" by wearing clothes or singing songs that are in fashion for them.

A major problem for the Irish hierarchy is that its claim to moral authority, and not just its video backdrop, appears to many to be frozen in time. Indeed, what was most notable about the opening words of Archbishop Martin quoted above was not his attempt to relate his speech on abortion to the image behind him but his assertion on behalf of the hierarchy that "we are at a defining moment for our country".

In fact, if there was ever a defining moment for the bishops, it had passed quite some time before he spoke. The Protection of Life during Pregnancy Bill of July 2013 was merely a late echo of any such definition rather than its signal expression.

The hierarchy resisted the proposed legislation as if it could turn back a tide. Yet the political power and influence of Irish bishops had long been on the wane. They had failed to swing votes in various earlier referenda on such matters as abortion and divorce and had not stopped the passage of legislation relating to birth control and homosexuality. Humanae Vitae had prompted Irish Catholics to question the realism of certain teachings of their church authorities and, once the laity had rejected them on contraception, people more readily than hitherto discounted other advice of celibate bishops on matters relating to reproduction and sexuality $^{2}$.

2. See, for example, Colum Kenny, Moments that changed us (Dublin, 2005), p 3-35. 
Nevertheless, during 2013 the bishops fought their corner in an assertive if not aggressive manner that alienated further those who tend to see the Irish hierarchy not only as out of touch but also, especially in light of their handling of clerical child abuse scandals, as dysfunctional.

For ten successive weeks from May to July 2013 the bishops had their Catholic Communications Office circulate special weekly "Choose life" bulletins for parishioners. They also sent briefing notes to all deputies and senators ${ }^{3}$. While unobjectionable in principle as a statement of their beliefs, these publications were in practice a crude and quixotic attempt to influence voters and politicians.

Bishops pressed priests to read at Mass explicit references to abortion that some of the laity found inappropriate in the presence of children. The hierarchy hinted at the excommunication of politicians who supported the legislation, ignoring more subtle positions taken on abortion votes by some other hierarchies, such as those of Uruguay and the United States ${ }^{4}$. A large number of "practising" Catholics, as well as many who today seldom enter a church but consider themselves to be Catholics in a residual sense, did not share the perspective of the bishops.

It is certainly not intended here to repeat the arguments of 2013 relating to abortion in Ireland, with minimalist legislation then being passed which the bishops still found lamentable. The debate has been revisited simply in order to demonstrate that the bishops project an image of themselves that itself constitutes a message. Such images, whether pictorial or constructed by way of association and positioning on various selected issues, constitute a mode of evangelizing that sings to their choir.

As it happened, later in 2013 certain sentiments of Pope Francis on the practice of religion and the assertion of moral beliefs came as a relief to many Irish Catholics following their hierarchy's attempt to exert influence by loudhailer. In that interview, given in August 2013 for publication in Jesuit periodicals, Francis said that, "The church's pastoral ministry cannot be obsessed with the transmission of a disjointed multitude of doctrines to be imposed insistently".

3. Bishops' briefing note on the Protection of Life during Pregnancy Bill 2013 [http://www.usccb.org/issues-andaction/faithful-citizenship/church-teaching/theological-reflections-tf-bishops-politicians-2004-06-13.cfm] (viewed 17 Oct. 2014)

4. Irish Independent, 5 May 2013 ("Cardinal [Brady] keeps excommunication threat hanging over abortion TDs", by B. McDonald); Irish Times, 6 May 2013; Sunday Independent, 12 May 2013 ("Brady...fudged it", by C. Kenny); Sunday Times, 19 May 2013 ("Archbishop Eamon Martin... said legislators who support abortion are excommunicating themselves", by L. Nolan and S. O’Brien); "Uruguay bishops clarify statement", by Catholic News Agency, 24 Oct. 2012 [http://www.catholicnewsagency.com/news/uruguay-bishops-clarify-statement-on-excommunication-of-lawmakers-favoring-abortion/] (viewed 31 Oct. 2013); Archbishop William Levada, "Catholics in political life and the reception of Holy Communion" (US Conference of Catholic Bishops, 13 June 2004), [http://old.usccb.org/bishops/reflections.shtml] (viewed 31 Oct. 2013).

5. The interview was conducted in person by Antonio Spadaro, S.J., editor in chief of La Civiltà Cattolica, the 
With Ireland consumed by a global and national economic crisis, with emigration rising again and social services contracting, it seemed to many citizens that the Irish bishops were out of balance in respect to everyday realities.

If there ever was "a defining moment" for Ireland, of the kind that the bishops had in mind, it was certainly not the enactment of legislation in 2013 that had long been anticipated following an earlier referendum and subsequent court judgments on abortion, and that opinion polls showed clearly most people deemed necessary in light of Savita Halappanavar's death. She had been refused a possibly life-saving abortion, with one hospital employee explaining that refusal by reference to Ireland's "Catholic ethos".

If there ever was a single moment when Ireland was defined as having crossed some kind of Rubicon in its relationship with Catholic bishops, it was more likely to have occurred seventeen years earlier. In August 1996, during his visit to Chicago and Detroit to attract financial institutions to Ireland, the Irish Minister for Finance Ruairi Quinn TD described his state as a "post-Catholic, pluralist republic" represented by an outstanding President. The latter reference was to President Mary Robinson, a human rights lawyer and liberal who had been elected president of Ireland in $1990^{7}$. Here, literally, was a definition. If at the time Quinn offended some people, and others regarded his statement as an expression of personal wishful thinking, in hindsight he seems to have been correct. Recent census returns disclose the vast majority of Irish people still recording their religion nominally as "Catholic", yet their level of attendance at church has fallen steadily and their attitudes and behaviour are in practice akin to what hitherto were regarded as Protestant or secular types. The term "à la carte Catholics" is sometimes used, often dismissively as a dining metaphor, to describe their exercise of conscience in respect to what they choose to take or leave in respect to Catholic dogma.

It is unlikely that Quinn was being deliberately provocative. He did not seek publicity for his comment. It was barely reported as the very last sentence of a story in the middle of page 7 of the Irish Times. He had been fielding a range of questions from Irish emigrants in the United States who remembered when their church's hand lay heavy on Irish social policy. Archbishop Desmond Connell retorted at the time that Quinn had spoken "in a way that seems to endorse a secular hostility to any Catholic influence on our national outlook ${ }^{8 "}$. Connell would later be discredited for his handling of child abuse cases in the archdio-

\footnotetext{
Italian Jesuit journal. Fr Spadaro conducted the interview on behalf of La Civiltà Cattolica, America and several other Jesuit journals around the world. See, for example, America, 209, no. 8 (30 Sept. 2013), p. 26.

6. Irish Independent, 10 April 2013.

7. Joe Carroll, “Quinn stresses good ties with Clinton”, Irish Times, 29 Aug. 1996.

8. Andy Pollak, “Archbishop Connell criticizes minister”, Irish Times, 16 Nov. 1996, p. 7.
} 
cese of Dublin, especially when he invoked the casuistic doctrine of "mental reservation" to defend himself after he made misleading statements. His response to Quinn was more pointed than that of the bishops and clergy in general, who may have sensed that the minister for finance was at least partly right. In an interview for the Irish Catholic four years later, Quinn said that he had merely meant that "we were post-Catholic in a political sense ${ }^{10}$ ". Foster has written that Quinn "got into trouble ${ }^{11}$ " for his remark but, significantly, insofar as he did so it was not much trouble.

If Quinn's words were a little startling in 1996, those of the Irish Taoiseach (prime minister) during the abortion controversy of 2013 were surprising for almost the opposite reason. Even in Taoiseach Enda Kenny's own quiet, rural constituency were there really such old-fashioned Catholics left? For Kenny told parliament, "I am getting medals, scapulars, plastic foetuses, letters written in blood, telephone calls all over the system", he said. This head of the conservative Fine Gael party in a coalition government spoke in a way that any Taoiseach of earlier decades would scarcely have dared, saying that, "I am proud to stand here as a public representative, as a Taoiseach who happens to be a Catholic but not a Catholic Taoiseach. I am a Taoiseach for all of the people - that is my job, while I have it ${ }^{12 "}$.

Enda Kenny's government had closed the Irish embassy to the Vatican, partly as a cost-saving measure when some other embassies were also shut and partly, observers believed, because of his government's displeasure at the Vatican's continued mishandling of Irish clerical sex abuse scandals. Some Irish bishops, and some bishops in the United States who subsequently absented themselves from events at which he was present during visits there, may have been eager to inflict a political defeat on him in respect to abortion especially because of his government's closure of the Vatican embassy ${ }^{13}$. Kenny had not helped to improve his relations with the hierarchy when in September 2012 he was seen busily texting on his cell phone while seated in the front row at Castel Gandolfo as Pope

9. Commission of Investigation: [Murphy] Report into the Catholic Archdiocese of Dublin, July 2009, Paragraphs 58, p. 19-22; Niall Murray, "Clergy used 'mental reservation' to mislead media without lying", Irish Examiner, 27 Nov. 2009.

10. Patsy McGarry, “Labour leader explains 'post-Catholic’ remark”, Irish Times. 20 April, 2000, p. 2.

11. R.F. Foster, Luck and the Irish: a brief history of change, 1970-2000 (London, 2007), p. 121. More recently, in January 2014, Quinn sparked controversy again when in his role as minister for education he suggested that Ireland's many church-run primary schools should consider using time allocated for religious instruction to improve pupils' literacy and numeracy skills (Irish Independent \& Irish Times, 25 Jan. 2014).

12. Dáil debates, 12 June 2013 (Leader's questions).

13. "Vatican embassy closure 'nothing to do with Cloyne", by Juno McEnroe, Irish Examiner, 5 Nov. 2011; "Is Cardinal George latest participant in Ireland-Vatican tiff”, by M. Sneed, Chicago Sun-Times, 23 Feb. 2012; "Cardinal [Sean O’Malley] skips Boston College commencement in abortion protest", Associated Press report, UK Guardian, 20 May 2013. 
Benedict read a speech to a delegation from the Centrist Democrat group of which Kenny's Fine Gael party is a member ${ }^{14}$.

In the run up to the Irish abortion controversy of 2013 the US hierarchy had been putting pressure on President Barack Obama concerning reproductive aspects of his health care policy ${ }^{15}$. Irish bishops may have seen this as an encouragement to them to exert greater influence on this side of the Atlantic. But politicians held firm and the new abortion law, albeit relatively restrictive compared to that of other European countries, was passed despite the displeasure of Ireland's bishops. Their defeat in the 2013 abortion debate left Irish bishops looking lost.

Meanwhile, buildings that were once a sign of their expanding influence have become visual millstones around their collective neck, tying them to an image of Christianity defined by its architecture of power and by decades of assertive moralism. Particularly associated with the hierarchy are the somewhat dreary walls and grounds of Maynooth, where Irish bishops hold their quarterly meetings. If maybe, once in a lifetime as the poet Seamus Heaney wrote, "hope and history rhyme" (The Cure at Troy: A Version of Sophocles' Philoctetes), it is certainly not here anymore.

From the eighteenth century onwards, but especially after 1829 when Irish Catholics won political emancipation, the Irish Catholic Church embarked upon a great building programme. Persecution and poverty had previously held it back. Now a rising middle class and a proud nation poured money into new churches ${ }^{16}$. Structures modeled on the classical and Gothic architecture of European religious heritage began to dominate Ireland ${ }^{17}$. In certain cases, such as that of Dublin's "pro-cathedral" or the Jesuit Church of St Francis Xavier, the architectural plan or some of the funding came from France ${ }^{18}$. For years, and well into living memory, people in Ireland noticed whether or not their local Catholic church rose higher than the Church of Ireland (Anglican) one. Irish Catholics saw their buildings as a physical manifestation of their parity of cultural esteem and, for some of them, soaring spires constituted a triumphalist statement. There had been for years a prohibition on steeples and bells for Catholic chapels ${ }^{19}$. New parish churches became powerhouses of Irish Catholicism. From the Great Famine until 1961, priests promoted a variety of devotions to rally the fullest possible congregations

14. "Taoiseach Enda Kenny under fire for using phone at meeting with Pope Benedict”, by Lyndsey Telford, Irish Independent, 25 Sept. 2012; "Taoiseach plays with mobile during Papal meeting”, Irish Catholic, 27 Sept. 2012.

15. See, for example, "USA bishops slam Obama's contraception exception as a 'gerrymander", by Tom Howell Jr., Washington Times, 21 March 2013.

16. Emmet Larkin, «Economic growth, capital investment, and the Roman Catholic Church in nineteenth-century Ireland,» American Historical Review, 72, no. 3 (1967), p. 852-84.

17. Brendan Grimes, "Funding a Roman Catholic Church in Nineteenth- Century Ireland", Architectural History, 52 (2009), p. 147-66.

18. Ibid., p. 148, p. 164.

19. R.F. Foster, Modern Ireland 1600-1972 (London, 1988), p. 21 
as they nurtured generations of emigrants and missionaries. Lay emigrants served as seed sown abroad from which culturally hyphenated Irish diasporic communities sprang. Ireland was a breeding ground for the soldiers of Catholic expansion, and these new stone structures its domestic fortresses. As the population of the new state approached its nadir in 1961, with just 2.1 million people remaining, Bishop Cornelius Lucey of the diocese of Cork and Ross alone supervised the erection of eight new churches between 1955 and 1962. He was by no means unique among his colleagues in his enthusiasm for building ${ }^{20}$.

When in 2013 citizens sent Enda Kenny medals and scapulars during the abortion debate, they were evoking that confraternal church of that earlier epoch. Few younger Irish people today know what a scapular is or represents, and few wear medals. Any cross that they wear is likely just a sign of general good will or respect for Jesus as a person. Once, within the lifetime of some of us, anxious mothers pinned scapulars to undervests or hung them with medals around their children's necks to keep sons and daughters safe and to bring them good luck. Members of confraternities and sodalities wore their particular medals proudly, as did the teetotal Pioneers their Sacred Heart of Jesus pin, to express good intentions. Militant religious movements that asserted worthy objectives mobilized within stone fortresses, and their members sported badges of allegiance as a matter of course.

Ought we to be nostalgic for such practices or to dismiss them as naïve superstitions, or even as signs of credulous servitude? I have recalled elsewhere that the image of the Sacred Heart meant much to our Irish ancestors and others, and have suggested ways in which that image might again serve useful, compassionate purposes ${ }^{21}$. Sodality medals and pioneer pins were part token and part talisman but in many cases they undoubtedly expressed the compassionate or otherwise worthy ambitions of those who wore them and were no less deserving of respect than any religious or secular aspirations for the betterment of life.

Likewise, we may assume that most Irish Catholics supported the ecclesiastical building boom and that it was not a hierarchical conspiracy to control local lay people. Yet it marked a change in the way that Irish Catholics related to their church. The erection of these buildings was part of a process that carried Ireland forward to the foundation of a state in which one of the pillars of power was a very visible church presence, where that church was firmly and centrally run by its bishops. In recent decades, as events eroded the credibility of the Irish hierar-

20. Anon., "The Great Ten Years in Caheragh", The Fold (diocesan magazine, June 1963), p 27-33; Richard Butler, "Architecture and the triumph of Catholic Ireland: a case-study of church building in rural Cork, 1953-55", Journal of the Cork Historical and Archaeological Society, p. 120 (forthcoming, 2015).

21. Colum Kenny, "Sacred heart, sacred mind: the challenge of conviction in the Catholic Church", in J. Littleton and E. Maher (eds), The Dublin/Murphy report: a watershed for Irish Catholicism (Columba Press, 2010), p. $37-47$. 
chy and as other circumstances modernised the perspective of Irish Catholics, the buildings with which a church triumphal had been associated no longer appeared as attractive as they once had been to so many. Attendance at Mass has fallen significantly, and a diminishing and ageing body of priests finds itself deployed as a sort of service industry to deliver baptisms, wedding ceremonials and funerals to people who frequently do not care for any other form of religious engagement with their local church.

It is always hazardous to speculate how such a broad a range of people as those who are categorised as Irish Catholics, whether "practising" or "lapsed" or otherwise described, imagine their own community of origin. But many certainly identify themselves with a tradition that is visually anchored in ruined monastic settlements such as those of Glendalough and Clonmacnoise, and in remnants of early Christian activity such as Gallarus Oratory and the beehive cells of Co. Kerry. I refer here to Gallarus Oratory as it was until not long ago (and as seen here photographed about 1960), sitting gently in the landscape before it was tidied up and surrounded by cement, with a wide path leading now to an adjacent car-park in the facilitating and soulless style of contemporary heritage tourism ${ }^{22}$. Many at school learnt that medieval Ireland came to be known as "the island of saints and scholars", and still like to believe that there was some truth behind that soubriquet. Irish church leaders who once boasted of their institution's standing in the world thereby set a standard by which their more recent successors have been judged and found wanting.

Today, one enchanting idea of the early church in Ireland is that it was pure and simple and quite independent of Rome. If somewhat romantic and even misleading, this idea appeals both to those who wish to stay within the Irish Catholic Church to see it reformed and those who prefer to reconcile themselves to the Christian message in other ways. The power of the idea has been evident perhaps most notably in the popularity of works by the late John O'Donohue (19562008) whose best-selling books such as Anam Cara (Gaelic for "soul friend") drew on and popularized a Celtic stream of spirituality. Some of those in authority in the church respond to recent popular interest in early Christianity by dismissing it as another sign of that "à la carte" approach to religion that dispenses with their guidance as to what is or is not true or permissible. They consider discussion of Celtic spirituality to be not only dogmatically unreliable but also intrinsically ignorant in many cases, and indeed they may be correct in particular instances. Nevertheless, the Celtic ideal or myth, and the images associated with it of early deserted holy sites by sparkling stream or sea, poses an enduring challenge.

22. For the oratory's modern setting, and to look inside "in virtual reality", see [http://www.voicesfromthedawn.com/ gallarus-oratory/] (viewed 17 Oct. 2014). 


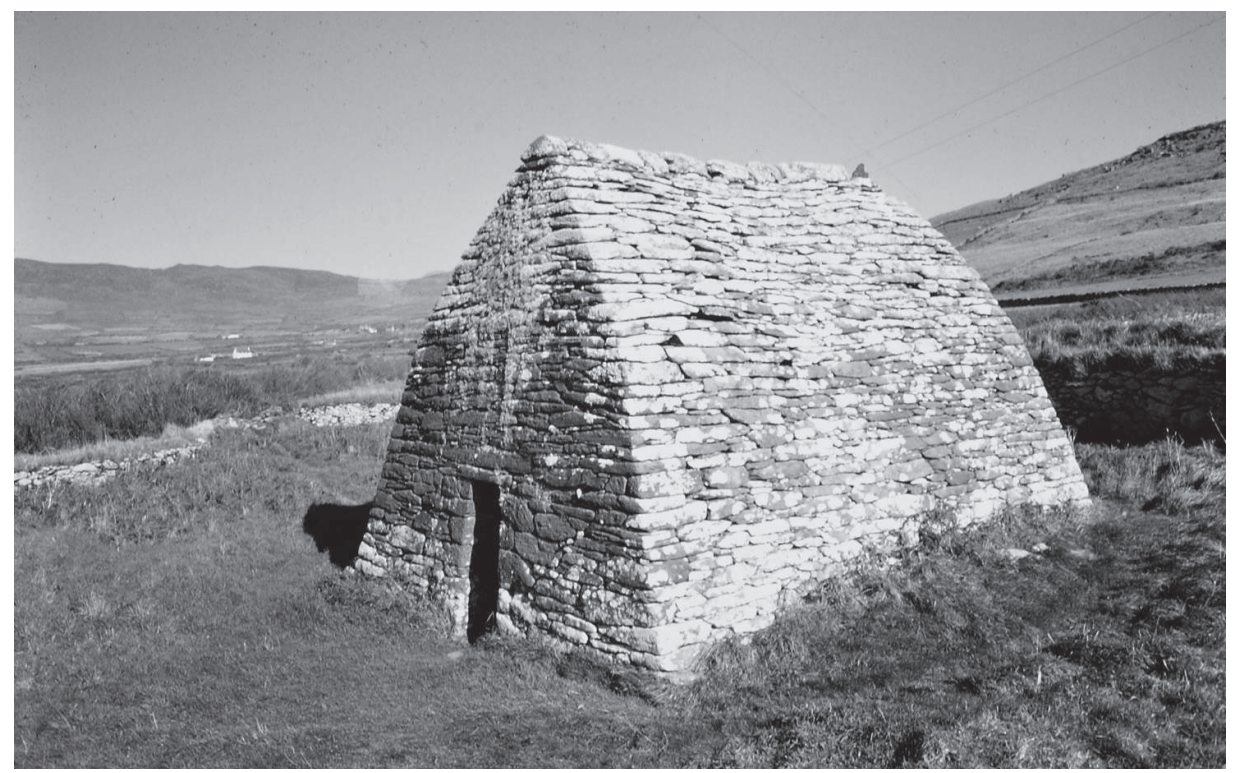

The movie in the heads of Irish Catholics that tells them their story does not jump suddenly from Celtic spirituality to the Catholicism of the more recent past. There are along the way cloudy sequences that involve monasteries destroyed during the Reformation, priests on the run facing penal persecution, visits to holy wells and a round of rural domestic devotion known as "The Stations". The fact that little of this history has been represented in Irish films or on television, and seldom even in still art, renders it no less powerful as a narrative of ancestral identity. It has been sustained by popular memory and by schoolteachers who evoked it in order to inspire their pupils for religious or nationalistic purposes.

One scarcely needs to add that such origin myths do not always precisely match historical fact. The Mass Rock found in many parts of Ireland was indeed used by priests in times of danger, but may also have been a simple and convenient place of worship for local people when a priest passed through their district. Any notion that the number of priests in Ireland fell only as a result of penal persecution does not appear to be born out by the impressive research of Emmet Larkin who notes ironically, for example, that "the decline in the number of clergy was not the result of Penal legislation by a Protestant government, but rather the effect of a series of Apostolic Rescripts from Rome because the Pope, Benedict XIV, had been persuaded that the number of priests in Ireland was too great and should be reduced ${ }^{23}$ ". Larkin's explanation for the subsequent rise in the 
number of both priests and Catholic chapels during the eighteenth century is surprising, because many Irish still believe that there was a steady decline in Catholic ministry from about 1600 until the winning of emancipation in 1829. However, it is the case that a sharp rise in the population of Ireland from the late eighteenth century meant that actual increases in the number of priests and places of worship were for some time quite outstripped by the number of Catholics being born, especially in poor areas.

The social and economic effect of penal laws enforced against Catholics, coupled with the impact of political union between Britain and Ireland from 1800 , strengthened the bonds between lay people and those priests who worked to help them improve their lot. The simple quality of Irish church buildings had its own special charm for such oppressed people. Whatever was built was theirs, and at one with their environment. Chapels that preceded the more architecturally ambitious churches built later in the nineteenth and twentieth may have had little external aesthetic appeal for middle class observers but they represented success for those who constructed them. Visiting a whitewashed chapel beside an ancient ruined abbey in Co. Galway in 1835, the French visitor Alexis de Tocqueville observed "a look full of joy and satisfaction" on the face of the local priest who accompanied him there:

You will see in a quarter of an hour, Sir, he said to me, a man who still remembers the times when mass was celebrated in a ditch, while a part of the congregation served as sentinels for fear of being seized by the agents of justice. Ten years ago when I came to this parish, we still celebrated the divine office in a barn. God be praised that we are now able to gather in a place that is consecrated only to the celebration of our holy mysteries; and this church, Sir, he added with an air of triumph, this church was built with the aid of voluntary contributions ${ }^{24}$.

The Frenchman's charming account goes on to describe how he accompanied the priest to the house of a dying man. Priests not only visited homes to minister to those about to die but frequently celebrated Mass in people's houses.

To those reared in Ireland during the early or mid twentieth century who recall the great social and clerical pressures on all Catholics to attend Mass weekly, it comes as a surprise to learn that no such requirement bothered the pre-Famine church. The bishops asked simply then that, at Easter, parishioners go to a priest to confess and take communion. And one's doing so did not necessarily involve even a visit to a church, for there were instead "The Stations". these involved prior to Easter and Christmas for six to eight weeks, the parish priest going each day to

24. Alexis de Tocqueville, Journey in Ireland, July-August 1835, ed. Emmet Larkin (Dublin, 1990), p. 122-124; Larkin, Pastoral Role, p. 185-6. 


\section{Colum Kenny}

a different lay person's house where he heard confessions and said Mass and where the congregation might afterwards celebrate with music and food and drink, storytelling and song ${ }^{25}$. The laity developed warm associations between faith and daily life, between priests and people, between religion and celebration. That is not to say that there were not occasionally extortionate abuses of the Stations and other clerical activities. Aloysius O’Kelly's Mass in a Connemara Cabin, painted during the $1880 \mathrm{~s}$, is a reminder of the ultimate religious and social distinction between the laity and even a young priest ${ }^{26}$.

Aloysius O'Kelly, Mass in a Connemara Cabin (c. 1883).

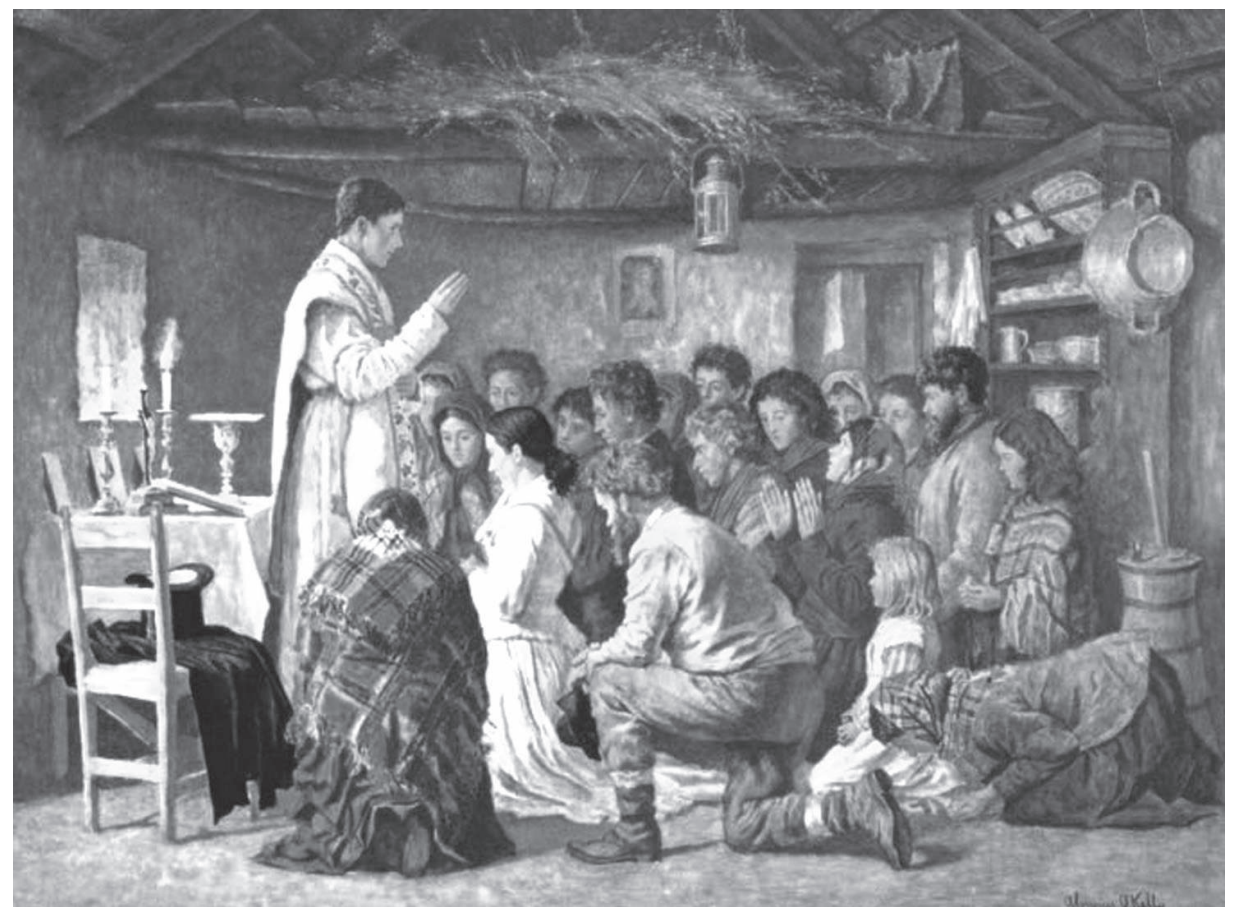

One particular priestly practice that developed and was sustained in some areas into the second half of the twentieth century was especially resented by many of the laity. This was the shaming and shameful custom of a local priest reading from the altar details of individual contributions donated by identified lay persons to church collections.

25. E. Larkin, “The rise of Stations in Ireland, 1750-1850", Pastoral Role, p. 189-58.

26. Niamh O'Sullivan, "Mass in a Connemara cabin: religion and the politics of painting", Eire-Ireland, 40, nos 1 $\& 2$ (Spring/Summer 2005), 126-39; Joseph Nugent, "Clerical errors: reading desire in a nineteenth-century Irish painting”, Éire-Ireland, 46, nos 3 \& 4 (Fall/Winter 2011), p. 27-36. 
The narrative of Catholicism in Ireland is founded on the link between the faithful and local hermits or priests, rather than between people and their bishops. In this context early tensions between Irish Christians and Rome about the date of Easter each year were long half-remembered with a sort of mischievous glee as an example of the waywardness and independent spirit of our ancestors. It was recalled ruefully that the pope appeared to have lent his blessing to the Norman invasion of Ireland. The pope's representative in Ireland in 1646, GianBattista Rinuccini, complained to Rome that the Irish church cared little for the splendor and grandeur of religion and that members of religious orders "have impudently gone on to prove that it is not necessary to the support of the faith to have churches, since in the Old Testament we are told that the Hebrews were for centuries without a Temple; and in the New that Christ instituted the Eucharist in a private house" at the Last Supper. He added that

none who have had Mass in their own room appear to care for any other mode of worship... even the lowest artisan wishes in sickness to hear Mass at his bedside; but often, to our great scandal, on the very table from which the altar cloth has been but just removed, playing-cards or glasses of beer together with the food for dinner are at once laid ${ }^{27}$.

The establishment of a national seminary at Maynooth, Co. Kildare, in 1795 was a turning point in the development of the Irish Catholic Church and its image. With seminaries that the Irish had attended in European countries closing during that revolutionary period, Ireland's bishops seized the moment to ensure "a more uniform and better-disciplined priesthood". The government not only gave them permission to open the Royal College of St. Patrick at Maynooth but also endowed it for many years. College authorities adopted a rigorous or even rigid approach to moral issues and an overtly loyal attitude towards the monarchy. Both positions were facilitated by a great French influence that arose from the college employing both émigré French priests and Irish teachers who had been educated abroad in the Gallican royalist tradition. It was even said that in the early nineteenth century French was the customary language of the professors' dining table, except for one end where Irish was spoken. Until 1868, staff at Maynooth took an oath of allegiance to the monarch, and students had to promise and declare that they were not and would not be "concerned in any latent conspiracy ${ }^{28 "}$.

27. The embassy in Ireland of the Monsignor G.B. Rinuccini, archbishop of Fermo, in the years 1645-1649. Transl. Annie Hutton (Dublin, 1873), p. 142.

28. G. Crolly, A life of the Most Rev. Dr Crolly, archbishop of Armagh (Dublin, 1807), p. xxiII; J.C. Beckett, The making of modern Ireland 1603-1923 (London, $2^{\text {nd }}$ ed. 1981), p. 256-7, 329; Michael Turner, "The French connection with Maynooth College, 1795-1855”, Studies: An Irish Quarterly Review, 70, no. 277 (Spring, 1981), p. 78, p. 83-4. 
Compared to the government's financial support for the established church, the amount that it gave for Maynooth was modest and the royal college's architectural development was of necessity restrained: "it is a positive fact, that the extensive pile of building, in which the students of Maynooth are now accommodated, has been raised by the hard-wrought economy of years, from the narrow means doled out annually by government", wrote one observer ${ }^{29}$.

Before long newly trained priests emerging from Maynooth became the spearhead of a burgeoning phalanx of clerics, monks and nuns with the total of all these rising, for example, from 5,000 for a Catholic population of five million in 1850 to 14,000 for just over three million in $1900^{30}$.

\section{St Patrick's College, Maynooth, Co. Kildare. Photo: Robert French, between 1865 and 1914. NLI L_Roy_09257.}

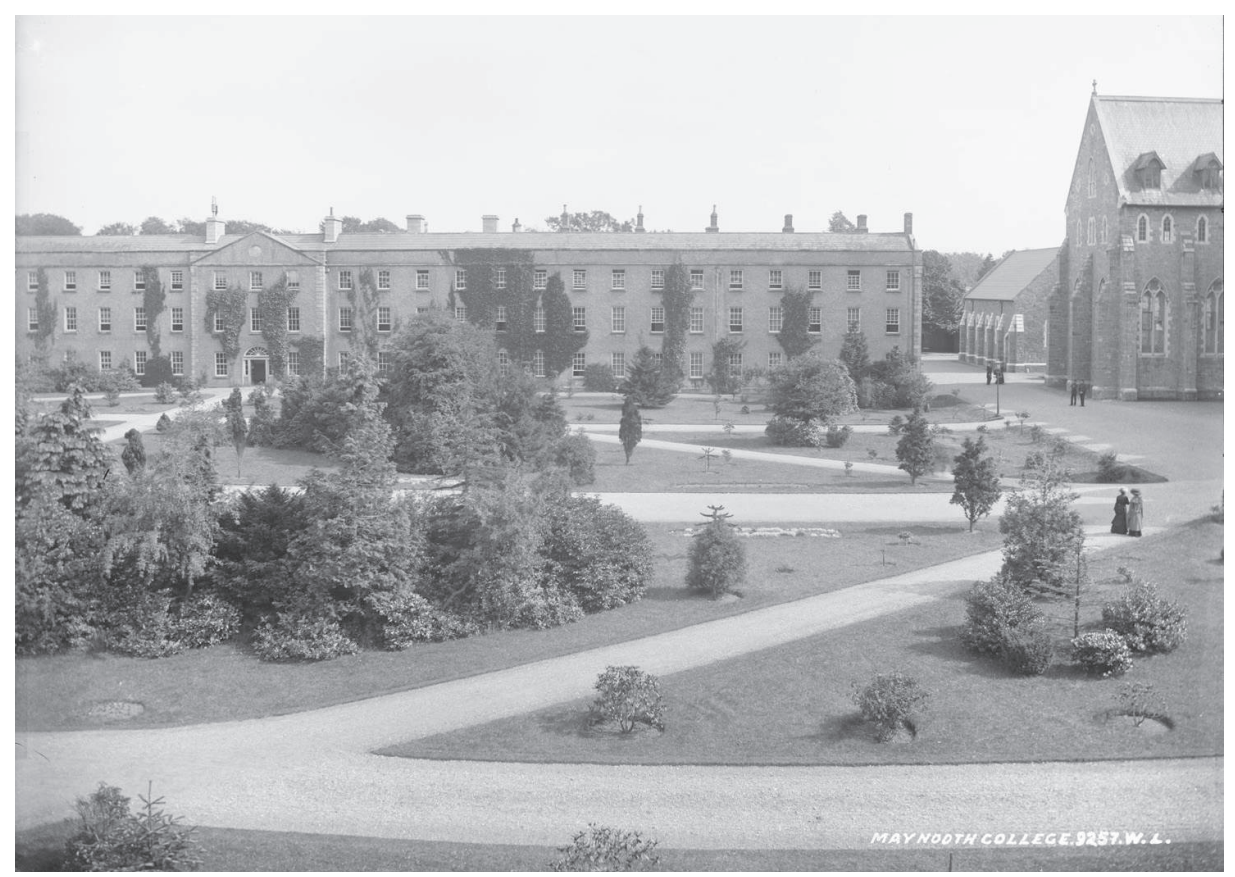

It lies far outside the scope of this essay to track the transformation of Irish Catholicism from a practice of the rocks and fields and homes and chapels to that of the powerful organisation that came to dominate Ireland from the late nine-

29. Anon., "Review of The Case of Maynooth College considered, with a history of the first establishment of that seminary; an account of the system of education pursued in it; and a review of the effect it has had on the character of the Roman Catholic clergy of Ireland (Dublin, 1836), [etc.]", Dublin Review, 2 (Dec. 1836 \& April 1837), 129-68 (quotation at p. 134).

30. Emmet Larkin, "Economic growth, p. 865, p. 1,254. 
teenth century. Leaving aside debates about the extent to which the pedagogic tone at Maynooth prompted Irish Catholicism towards a kind of Jansenism, as well as political questions concerning the implications of its accepting endowment by the government of the United Kingdom and of its priests taking an oath of allegiance, the very fact that the bishops of Ireland could now within Ireland closely control the training of their clergy eased the way for organizational initiatives and liturgical orthodoxy. During the nineteenth century there was a centralization of communal devotional practices, moving them away from homes and holy wells where popular gatherings had sometimes given rise to scandal and into the colder confines of elaborate buildings that proudly boasted the new status of Catholicism in Ireland. It also involved what Larkin described as "the institutionalization of the Irish bishops as a body" and their assertion - by no means always for the worse - of a stricter discipline over their priests ${ }^{31}$.

But the popular mind never entirely forgot how things had been, and the popular heart was still warmed by its association with old places and practices. The soundtrack that accompanies the narrative inside Irish Catholic heads frequently features the hymn "Faith of Our Fathers", amplified loudly and proudly at hurling matches and through loudspeakers at special religious events. Ironically, the hymn itself was written by an English convert to Catholicism, and the faith of which it boasted had by the time of its author's death in 1863 already in Ireland begun to take a form quite far removed in many ways from that of the ancestors of Queen Victoria's Irish subjects.

One of the factors that bound Irish peasants to their priests was illiteracy, with priests being keepers of the gospel books and other testaments from which they read. Printing came late to Ireland and when it did, in the sixteenth century, the first volume printed was a prayer book in the Irish language and in a form acceptable to Protestants. Later, as education became more widespread during the early nineteenth century, Protestant missionaries distributed bibles and encouraged their use as a direct means of relationship with the divine. Catholic priests in response strongly discouraged the unmediated reading of scripture, and continued to do so into the twentieth century. My own late mother told me that she recalled being instructed as a child not to read the Bible. The strength of this prohibition is reflected in some of the poetry of that wandering Galway and Mayo minstrel, Antoin Raftery, who depended on priests for hospitality and approval in the years immediately before Ireland was devastated by the great famine. They are said to have encouraged him to baptize babies when he encountered them in danger of death. Verses of the 1830s attributed to him indicate that the Counter-Reformation was a fact of religious life in the remotest parts of rural Ireland, and that

31. Emmet Larkin, The consolidation of the Roman Catholic Church in Ireland 1860-70 (Dublin, 1987), p. Xv. 
there was a continuing need to assert control over Catholics. Raftery wrote, "To the people of the false Bibles do not submit in future, Who never bow to priest or friar... But trust ye the clergy and the discourse of the Church, And the holy sermon that saints and apostles have written for us; Do not seek the Bible, or it shall come across you [trip you up] ${ }^{32}$ ". A rationale for such sentiments was formally expressed about this time in a defence of the syllabus of the Royal College of St Patrick, Maynooth ${ }^{33}$.

Catholic authorities have long recognised not only the power of unmediated words but also the mediated power of imagery, not least to command respect and loyalty. Protestant reformers have objected to some of the excesses of Catholic statuary and other forms of representation, and iconoclasts have directly attacked physical objects of art and devotion. But it can be easier to break stone than to uproot or supplant images and ideas within peoples' heads. For emotional and personal reasons we do not quickly let go what is dear to us, or what is part of our identity. This is especially the case when we believe that there is a meaningful continuity between the old and new. The old remains bedrock, a self-image on which we may fall back when disappointed.

So when a catastrophe befalls an institution, such as that brought upon the Irish Catholic church by those of its clergy and bishops who engaged in the sustained abuse of children or in the mismanagement and covering up of such abuse, individual members of that institution revert to ideas of their faith that sustain them. Such ideas command the heart and are associated with celebration rather than condemnation. When institutional crime, sin and mismanagement are coupled with an authoritarian emphasis on dogmatic orthodoxy in matters such as birth control and homosexuality and with a failure to grasp the significance of social change then lay people simply look elsewhere for escape or inspiration. The institutional church has lost them, but they have not necessarily lost faith in a Christianity that they believe may still address their needs and speak to their experiences of life.

How might church authorities reach out to the laity in ways that would breathe new life into the institution and, indeed, into its underused buildings? The Catholic Church has long understood the value of public relations and of messages that do not merely evangelise on the basis of the gospels but that project an appropriate image of the church. From early in the twentieth century, books, films and music were used in Ireland and elsewhere to promote the cult of the Virgin Mary in a way that deliberately countered the effect of communist propa-

32. Abhráin atá leagtha ar an Reachtúire OR Songs ascribed to Raftery, ed. Douglas Hyde (Dublin, 1903), p. 79-80, p. 115-7, p. 259; Desmond Bowen, The Protestant crusade in Ireland 1800-70 (Dublin, 1878), p. 71-6 for the Galway context.

33. Dublin Review, 2, p. 152 (see n. 28 above). 
ganda. During the visit of Pope John Paul II to Ireland in 1979 and afterwards, into the period of its failure to respond adequately to child abuse, the Irish hierarchy retained sophisticated public relations advisors who were accustomed to acting for tobacco companies and other corporate clients. But even the very best of communications experts cannot make a silk purse out of a sow's ear. What is needed is a message that matters, and in the case of a spiritual organization that message must come from the heart and be matched by practice and by respect for the other or it will always sound false.

Meanwhile, the bishops are saddled with their inheritance of heavy stone. All those buildings that once seemed like so many statements of success, albeit in too few cases aesthetically brilliant, now reproach their guardians and echo to the footfall of departing congregations. This was somewhat inevitable, as Protestantism and expressions of alienation such as those of the poet Elizabeth Barrett Browning ("Sonnets from the Portuguese, n43") or Matthew Arnold ("Dover Beach") and the ideas of French philosophy came to seem quite understandable to educated and broadly informed Irish Catholics in later twentieth-century Ireland. But the sad tones of ageing priests who speak from their altars with a sense of loss suggest that they recognise an opportunity foregone. As do the more urgent tones of the Irish Association of Catholic Priests. It did not have to be quite like this. And the sympathy of lay people for the plight of priests and nuns is redolent of an older affection and connection between priests and people that de Tocqueville encountered more than once: "The clergy, rebuffed by high society, leans entirely towards the lower classes. They have the same instincts, the same interests, the same passions as the people. A state of affairs altogether particular to Ireland...", he wrote at Carlow in $1835^{34}$.

At least four times each year the Irish bishops meet at St Patrick's College, Maynooth. Its continued use as a backdrop for meetings of an ageing and male hierarchy that has continued as a matter of priority to fight old battles simply perpetuates a visual image of decay. The college hastily added a full-length portrait of Cardinal Desmond Connell to the gallery of oversized, outdated and generally mediocre episcopal portraits that adorn its corridors. It was a defiant statement out of kilter with the times and especially out of keeping with public sentiment towards that particular prince of the church. Its appearance speaks not of art but of artlessness.

The producers of too many television programmes about sex abusing priests in Ireland have resorted during voiced-over passages to the visual cliché of a dark church interior with a few candles flickering weakly and the sound of a haunting choir. Nevertheless, the imagery is understandable. For, if God is light, the institutional Catholic Church in Ireland today represents darkness for too many.

34. De Tocqueville, Journey in Ireland, p. 48. 
How might Jonah emerge from the belly of the whale? Can the upturned boat ever be refloated? Although written almost half a century ago, Seamus Heaney's short poem entitled "In Gallarus Oratory" offers hope to Irish Christians today at times of institutional discouragement:

You can still feel the community pack This place: it's like going into a turfstack, A core of old dark walled up with stone A yard thick. When you're in it alone, You might have dropped, a reduced creature, To the heart of the globe. No worshipper Would leap up to his God off this floor.

Founded there like heroes in a barrow, They sought themselves in the eye of their King Under the black weight of their own breathing. And how he smiled on them as out they came, The sea a censer and the grass a flame ${ }^{35}$.

Irish Catholicism requires a new institutional image if it is to be regarded widely as relevant to people's inner and outer lives today, and as a means of connecting them to what is transcendent: "The sea a censer and the grass a flame."

In one paragraph headed most relevantly to this discussion, "Words which set hearts on fire", Pope Francis has recently written in an apostolic exhortation that, "Dialogue is much more than the communication of a truth. It arises from the enjoyment of speaking and it enriches those who express their love for one another through the medium of words. This is an enrichment which does not consist in objects but in persons who share themselves in dialogue. A preaching which would be purely moralistic or doctrinaire, or one which turns into a lecture on biblical exegesis, detracts from this heart-to-heart communication ${ }^{36} \ldots$.. He concluded, "Greater possibilities for communication [...] turn into greater possibilities for encounter and solidarity for everyone ${ }^{37 "}$.

On 1 July 2014, Coadjutor Archbishop Eamon Martin met a group of journalists who cover religious stories. The hierarchy's media office had arranged the encounter, which took place in Maynooth. Martin said that he wants a new

35. In Gallarus Oratory, in Heaney, Door into the dark (London, 1969). On one occasion Heaney walked a muddy path by a potato field to this "beehive early Christian church" only to find American tourists "all cameras and loud talk, shooting one another with the church for background. They were more interested in an interesting setting for their own likenesses than anything else. It was the kind of place where one could have sat alone, just in the presence of the past. But not today." (NLI MS49,493/5, Heaney Literary Papers, notebook, 19 Aug. 1966).

36. Evangelii gaudium (The Joy of the Gospels, Rome, 24 Nov. 2013), par. 142.

37. Ibid. par. 87. 
kind of communication between church and society. He expressed interest in the motivations of those present and acknowledged that media has an important role to play, but avoided any commitment to specific changes. He used the word "encounter" to describe the relationship that he seeks with media, although he sometimes slipped into using the word "church" as if it designates the hierarchy. On 8 September 2014 Martin succeeded Cardinal Seán Brady as Archbishop of Armagh and Primate of All Ireland. It has yet to be seen if his aspirations for encounter mark a distinctly new phase in the communicative relationship between the Irish hierarchy and the public in general.

Catholic leaders should embrace the media not as a mere mode of information transfer and "talking down" but rather as a means and a place to meet the world half way. Then communication can be part of a process of conversation and reasoning that will come to be regarded by the public as intrinsic to the institution. Insofar as the actual conditions of media ownership, control and editing permit this process of encounter to occur freely, they will allow the substance of a compassionate and listening church - if such indeed it is - to become also its image for the twenty-first century. 